\title{
Etnografia w skale: mapy topograficzne a doświadczenie wspinaczki
}

\author{
Ethnography in rocks: topographic \\ maps and the experience of climbing
}

\section{Wstęp}

Rozważania na temat praktyk cielesnych należą do tematów, z którymi współcześni etnografowie mierzą się coraz chętniej i częściej. Dlatego okiem etnografa przyjrzę się szczególnej formie takiej praktyki - wspinaczce. Interesuje mnie wspinaczkowe doświadczenie oraz specyficzny proces przekładu i wytwarzania wiedzy. Zastanawiam się, jak mapa topograficzna, we wspinaczkowym żargonie zwana potocznie „topo", jest w trakcie wspinaczki przekładana na ucieleśnione i wielozmysłowe doświadczenie obcowania z żywą skałą. Punktem wyjściowym dla tej refleksji jest zatem problem mapy topograficznej i związanej z nią wiedzy zestawionej z realnym doświadczeniem reprezentowanego świata. W wyniku tej konfrontacji, wśród wspinaczy dochodzi do gwałtownej epistemologicznej oraz ontologicznej ekspansji. Zjawisko to omówię na przykładzie problemu kinestetycznej estetyzacji dróg wspinaczkowych, a następnie przejdę do kwestii związanych z doświadczeniem wspinaczkowego habitusu oraz umiejętnym poruszaniem się - lub jego równie umiejętnym zaniechaniem - w środowisku skalnym. Uważam, że elementy te stanowią swoiste kontinuum doświadczenia wspinania, są, można rzec, jego istotą: wspinanie to transformacja wiedzy i doświadczenia, konfrontacja pozornie redukcyjnej i okulocentrycznej reprezentacji świata zawartej na mapie z wielozmysłowym i angażującym doświadczeniem bycia w świecie. 
Topo to najogólniej mapa drogi wspinaczkowej, dla wielu to także pierwsza forma wiedzy o danej drodze. Na topo wspinacz znajdzie informacje o czekających go trudnościach i rodzajach formacji, które będzie musiał pokonać. Jednakże topo to również skała poddana obiektywizacji, to zbiór zakodowanych informacji, doświadczeń oraz wiedzy wytwarzanej przez wcześniejsze generacje wspinaczy. Jak zauważają Hayden Lorimer i Katrin Lund (2003), błędem jest zatem założenie, że ta wiedza jest odcieleśniona i złożona z „obiektywnych” faktów. Mapy nie są abstrakcyjnymi przedstawieniami przyrody, a reprezentacjami złożonych społecznych praktyk przestrzennych.

Skały i góry od dawna uwodzą aurą grozy, a ich zdobywanie daje poczucie pokonania czegoś, choćby własnych ograniczeń obnażanych przez surowość górskiego krajobrazu (Kolbuszewski 2020). Wspinaczka to także forma transgresyjnego doświadczenia, to balansowanie między światem kultury a tym światem, który wydawałoby się znajduje się poza nim. Jak zauważa Marek Pacukiewicz (2012), wspinaczka odsłania przed wspinaczami ontologiczną grań, po której biegnie granica między tym, co kulturowe, a tym, co naturalne. Akt wspinania to więc umiejętne poruszanie się po tej granicy, to doświadczenie „żywych gór” i wsłuchanie się w ich język (Shepherd 2011). W tym sensie wspinacze przypominają szamanów, którzy, pogrążeni we wspinaczkowym transie, dotykają i słuchają skały przed osadzaniem w niej sprzętu do asekuracji (krucha czy lita?) oraz wykonują szereg innych rytualno-magicznych działań, by droga, żargonowo mówiąc, „puściła”1. Wspinaczka jest więc doświadczeniem, które opiera się na wyszkolonym operowaniu ciałem w przestrzeni dostępnej jedynie dla wąskiego grona. Poprzez wielozmysłowe zaangażowanie wspinacza, wspinaczka jest epistemologicznym aktem, w którym ciało poznaje drogę, na którą składają się nie tylko graficzne symbole, ale także faktura skały, jej wilgotność, kształt, zapach, temperatura, specyfika stopni oraz chwytów, właściwa sekwencja ruchów oraz współpraca i zaufanie do osoby asekurującej. Wspinaczka to zatem cielesny, emocjonalny i na swój sposób fenomenologiczny stan określany w żargonie jako „beta”, właściwa sekwencja ruchów, dzięki której w najprostszy sposób wspinacz pokonuje kolejne metry skały. Moje pytania zatem brzmią: jak wytwarzana jest warstwa wiedzy i doświadczenia określana tym mianem; jak wygląda tranzycja z wiedzy pierwszej, wydawałoby się zobiektywizowanej, ku subiektywnej wiedzy beta?

\section{Ciało i skała}

Etnograf stale zapoznaje się z mapami, szczególnie lokalnymi, wyrysowanymi przez lokalnie „profesjonalnych” kartografów, ludzi, którzy, jak zauważa Tim Ingold (1993, 2000), „zamieszkują” (dwell) lokalny krajobraz. Zamieszkiwanie to aktywne i wielozmysłowe

1 Podczas badań zauważyłem, że wielu wspinaczy ma swoje drobne rytuały: kolejność zakładania sprzętu, zakładana butów (najpierw prawy lub lewy), dotykanie skał w drodze pod ścianę, sposób mocowania sprzętu do uprzęży, nacieranie dłoni magnezją - to tylko nieliczne przykłady. 


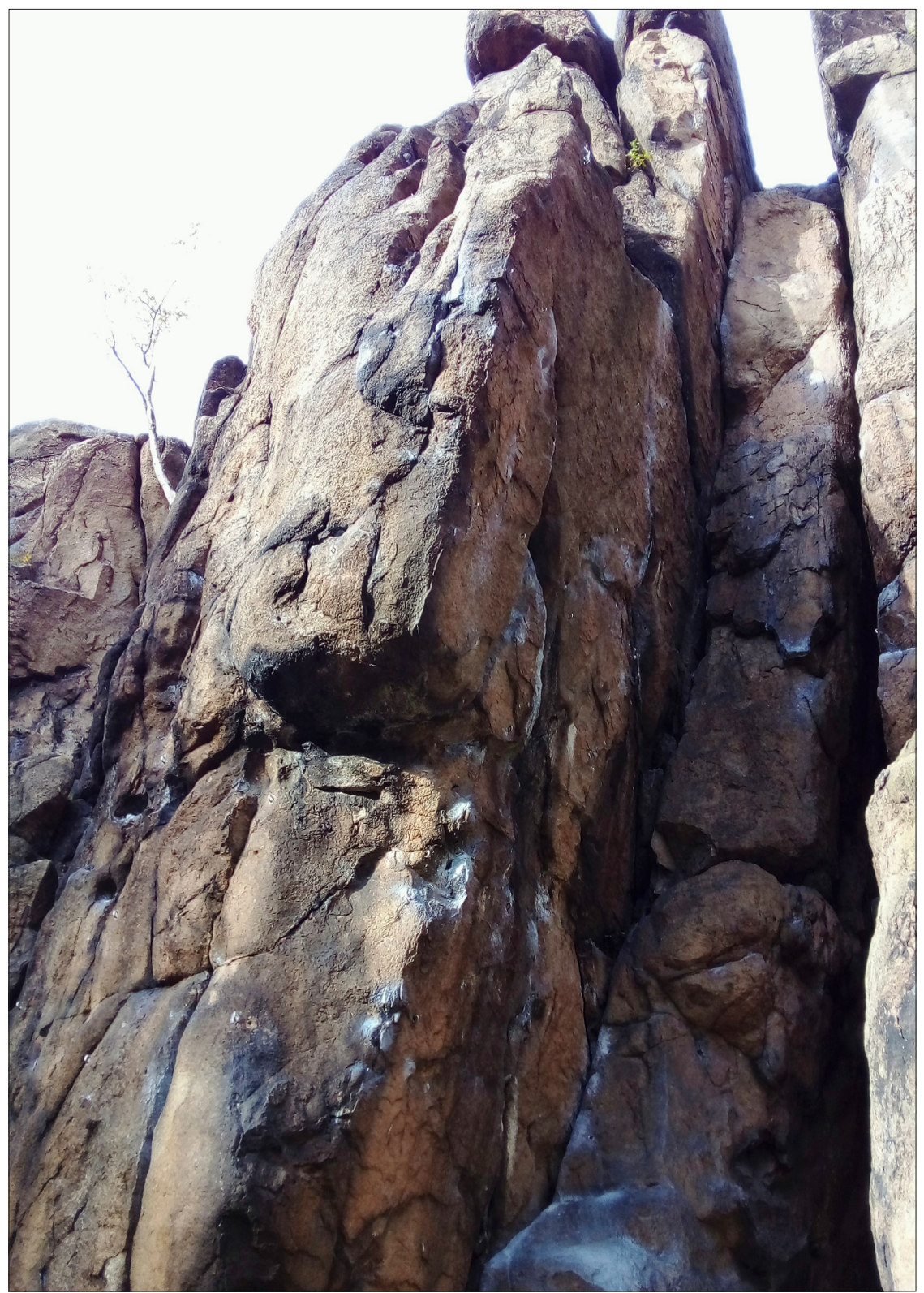

Fot. 1.

Widzialna droga; Sokoliki, 2020 r.

zaangażowanie i równoczesne wytwarzanie przestrzeni przy pomocy określnych działań i dziedziczonych umiejętności (Ingold 2000: 5). Świadomość użytkownika danej przestrzeni rodzi się wiec na styku jednostkowego i społecznego zaangażowania, percepcji i pojmowania krajobrazu, jego historyczności, mapowania i odnajdowania 
w nim właściwych dróg - tych fizycznych, jak i mentalnych. Przestrzeń zamieszkiwana to przestrzeń praktykowana i dziedziczona, a krajobraz „jest ustanawiany jako trwały zapis, a także świadectwo życia i pracy minionych generacji, które zamieszkiwały go i tym sposobem pozostawiły w nim swoje ślady" (Ingold 1993: 152).

Podobnie jak Ingold postrzega zamieszkiwanie krajobrazu, tak ja postrzegam wspinaczkę. Wspinacz musi drogę „zamieszkać” dzięki wiedzy i umiejętnościom wypracowanym przez poprzednie generacje. Wspinając się wspinacz przekształca bierną „naturę” W „środowisko” zupełnie tak, jak chce Ingold, czyli poprzez interakcję z przestrzenią. Jednakże krajobrazy, tak jak drogi wspinaczkowe, to księgi pamięci, a mapy topograficzne to symboliczne reprezentacje wiedzy kumulowanej przez kolejne generacje wspinaczy. Drogi, szczególnie w górach, mają swoich pionierów, od nazwisk których często nadaje im się nazwę. Wiedza pozostawiona po tysiącach wspinaczy jest czytelna w skale - drogę, szczególnie w skałkach, dosłownie widać, gdyż wyznaczają ją metalowe elementy do asekuracji (ringi, spity, haki) lub ślady po magnezji, a także czuć, gdyż poszczególne chwyty dotykane przez kolejne generacje wspinaczy zostały wygładzone.

Wspinaczka jest aktem wymagającym także specyficznej dyspozycji cielesnej, którą za Kirsten Hastrup (2018) określam mianem „świadomości mięśniowej” (muscular consciousness). Wiedza o świecie to, jak głosi Hastrup, rezultat procesu rozumienia, u podstaw którego leży ciało i jego zaangażowanie w świat. „Wiedzieć” to znaczy stawać się człowiekiem poprzez zaangażowanie w świat i poprzez zasiedlanie go ciałem. Wiedza jest więc kinestetyczna - wywodzi się z ruchu, przemieszczania się w czasie i przestrzeni. Tak jak czynią to badani przez Hastrup arktyczni myśliwi, tak też działają w ruchu wspinacze, których relacja ze skałą wyłania się z angażującego kinestetycznego aktu wymuszającego specyficzną świadomość ciała. Świadomość mięśniowa to więc aktywna odpowiedź na zastane warunki fizyczne, przestrzenne i wreszcie historyczne. Hastrup bowiem pojmuje naturę „jako przestrzeń historyczną”, a więc zamykaną w kategoriach takich jak geografia, krajobraz, ruch i historia właśnie (1994). Jednakże wyraźniej niż Ingold akcentuje ona rolę teraźniejszości i przyszłości. „Wiedzieć” bowiem, to nie tylko czerpać z i reagować na przeszłość, ale przede wszystkim umieć działać teraz i prognozować przyszłość. Taką sztukę Hastrup określa mianem „przywidywania” (forecasting) (2018: 122-124) i definiuje ją jako uważną obserwację i zdroworozsądkowe wnioskowanie, na bazie których ludzie podejmują dziatania oraz wytwarzają relacje z pozaludzkimi agentami. We wspinaczce reagowanie

2 Drogi dzielą się na ubezpieczone (sportowe) i przeznaczone do wspinaczki tradycyjnej, bazującej na tzw. asekuracji własnej. Te pierwsze są „obite”, czyli rozmieszczono na nich metalowe punkty, do których wspinacz wpina tzw. ekspres, a następnie do ekspresu wpina linę. Ubezpieczone drogi uważane są za bezpieczniejsze. Drogi przeznaczone do własnej asekuracji wymagają umiejętnego osadzania sprzętu do asekuracji - kości, „friendów” itp. - do których następnie wpina się ekspresy i linę. W razie odpadnięcia wspinacza od ściany, źle założona asekuracja może wypaść ze szczelin. 
i wnioskowanie są kluczowe - wspinacz musi wnioskować o przebiegu drogi i wykonywać operacje przenoszącego go niejako w przyszłość. Jest to więc wielozmysłowy proces nabywania oraz egzekwowania określonych umiejętności i wiedzy, który Hastrup określa mianem enskilment (2018: 118). Na ten proces składają się wieloletni trening i doświadczenie wspinacza, ale także jego wnikliwa umiejętność przekładania mapy topograficznej na sytuację zastaną w skale. Chwile, w których wspinacz - jak się mówi w środowisku - „wstawia się w drogę”, to „surowe momenty” (raw moments), czyli „stopnie wiedzy oraz przeżywane narracje (...) naładowane emocjami. (...) Surowe momenty odzierają nas z konceptualnych sądów i przenoszą w kierunku czystego doświadczenia" (Hastrup 2010: 204). Ten właśnie moment uważam za etnograficznie gęsty.

Nieliczne, ale inspirujące przykłady badań wśród wspinaczy, potwierdzają moje rozumowanie. Myślę tu o etnograficznych badaniach opartych na obserwacji i cielesnym uczestnictwie, autorstwa Andre Goodricha (2004) oraz Jana Dutkiewicza (2015). Goodrich zadaje pytania o to, jak ciało wie, gdzie jest i jak powinno działać w danych warunkach. W poszukiwaniu odpowiedzi wspinaczowi ma pomagać umiejętność rozpoznawania cech skały i dopasowywania do niej typów ruchu oraz „pamięć topokinestetyczna" (topokinesthetic memory) (2004: 30) - symulacja możliwych rozwiązań i dostępnych ścieżek w skale produkowana in situ. Goodrich odrzuca więc graficzne i mentalne reprezentacje dróg wspinaczkowych, uznając je za przeszkodę w budowaniu dynamicznej relacji między wspinaczami a światem zewnętrznym. Jest to więc propozycja w pewien sposób ahistoryczna.

Dutkiewicz również osadza swoje badanie w haptycznym i sensorycznym świecie (2015: 26-28). Wspinaczkę, w odróżnieniu od Goodricha, traktuje jednak jako złożoną praktykę społeczną i przestrzenną, której efektem jest nauka posługiwania się ciałem i jego szczególna świadomość - „wspinaczkowy habitus” (climbing habitus) (2015: 25-26). Wspinaczka to więc relacja zawiązująca się między ciałem a obiektem, jednakże jest ona osadzona w świcie lokalnych wspinaczkowych wartości, w opowieściach i społecznych wymiarach tej praktyki - ma, podobnie jak drogi, swoją lokalną historię i dziedzictwo.

Wspinaczka, jak zauważają Penelope Rossiter (2007) i Sally Ann Ness (2011), to również interakcja pomiędzy człowiekiem a nieożywionymi agentami - krajobrazem i skałą. Ness odkrywa, jak poprzez bouldering (wspinaczka niewymagająca liny) wspinacze konstytuują relacje z „kultowym” krajobrazem parku Yosemite. Rossiter zaś głosi, że akt wspinaczki to negocjacja wikłająca przynajmniej trzech agentów - skałę, technologię oraz wspinacza. To dzięki tej interakcji urwiska stają się urwiskami, a pokonujący je ludzie wspinaczami (2007: 293). Jest to więc proces konstytuujący samo pojęcie skały i tożsamość wspinacza, jednakże, jak twierdzi Rossiter, to także dialog z niematerialnym bytem, podczas którego zaciera się granica między podmiotem-użytkownikiem a używanym obiektem. 


\section{Ciało i metoda}

Po pierwszych rozmowach ze wspinaczami zauważyłem, że próbowałem rozmawiać o fenomenach, które nie mieszczą się w porządku językowym. Język zawodził podczas wyrażania emocji związanymi z wysokością, trudnościami technicznymi, sposobami trzymania chwytów oraz barierami psychicznymi i fizycznymi, z którymi wspinacz musi się zmierzyć. Nie oznacza to jednak, że porzuciłem klasyczne metody pracy etnograficznej, takie jak wywiady czy obserwacje. Były one dla mnie cennymi źródłami wiedzy, bez których nie sposób przecież tworzyć etnografii. Prowadziłem zatem rozmowy ze wspinaczami i instruktorami, obserwowałem ich metody pracy, a także proces przyswajania umiejętności poruszania się w skale. W większości treść wywiadów i wnioski z obserwacji streściłem w notatkach terenowych. Nagrałem tylko nieliczne wywiady, gdyż świat, który badałem, był nieustannie w ruchu - nie było więc mowy na dogodną przerwę na wywiad. Zresztą, choć ciągle cenny, wywiad nie wydaje mi się najtrafniejszą strategią pozyskiwania danych w tak nakreślonym terenie badań. Szybko bowiem pojąłem, że taka etnografia będzie przede wszystkim bazowała na partycypacji, zaangażowaniu i doświadczeniu, będzie cieleśniona i rejestrowana przy pomocy ciała zaangażowanego w badany świat. Będzie zatem - do pewnego stopnia - autoetnograficzna, choć zawsze wynikająca z bliskiej i unikalnej interakcji z drugim człowiekiem, partnerem, z którym łączyła mnie lina i łączyć musiało zaufanie oraz poczucie współzależności.

Z pomocą przyszła mi „gęsta partycypacja” (thick participation), a więc metodologia zaproponowana przez Jaidę Kim Samudrę (2008), choć podobne sposoby prowadzenia badań znane są ze szkoły antropologii fenomenologicznej i socjologii sportu. Samudra, badając adeptów sztuki walki silat, pytała: jak badać doznania i praktyki cielesne, które wymykają się językowej ekspresji? Swoją propozycję wywodzi więc ze studiów nad „kulturami ruchu” (kinesthetic cultures) (2008: 666), u podstaw których leży fenomenologiczna refleksja nad wiedzą płynącą z doświadczenia, ciała oraz jego społecznego ugruntowania. Gęsta partycypacja to próba przełamania Kartezjańskich modeli poznania, to metoda poznawania i wytwarzania wiedzy, która, zanim jeszcze zostanie zamieniona w tekst, kumuluje się w ciele badacza. Tak jak Geertzowski opis gęsty, gęsta partycypacja skupia się na detalu, jednakże, jak zauważa Samudra, nie aspiruje do jego tłumaczenia - nastawiona jest na podzielanie cielesnych i społecznych doświadczeń.

Jednakże należy zastanowić się nad rzeczą badawczo praktyczną - jak przełożyć zebrany (doświadczony?) materiał na język naukowej analizy? Doświadczenia cielesne, jak zauważa przecież Samudra, wykraczają często poza możliwości aparatu językowo-pojęciowego. Badaczka mówi więc o „tłumaczeniu doświadczenia” (2008: 668), choć użycie pojęcia „łłumaczenia” to jednak zwrot ku Geertzowi. Samurda rozwiązuje ten paradoks, choć w moim odczuciu nieskutecznie, poprzez wprowadzenie do analizy 
materiału szeregu „taktyk” (2008: 668-677) ukierunkowanych na rozpoznanie i zrozumienie konkretnych problemów. Podążając za definicją taktyk zaproponowaną przez Michela de Certeau (1984), dokonuje próby przełożenia partycypacyjnego zrozumienia (participatory understanding) wytwarzanego jeszcze w czasie pracy w terenie na dostępne kategorie poznawcze i narracyjne struktury języka - tego, co możliwe jest do powiedzenia, czego powiedzieć się nie da, a także czego powiedzieć się nie powinno o świecie, który badała.

Samudrze nie udało się skutecznie zdystansować wobec translatorycznych i interpretacyjnych praktyk znanych z Geertzowskiego opisu. Uważam jednak, że jej propozycja przenosi debatę o antropologicznej epistemologii na nowy poziom. Podejście, w którym badacz i jego ciało stanowią aparaturę rejestrującą, a zarazem także wytwarzającą wiedzę, choć powtarza wcześniejsze ustalenia chociażby Kirsten Hastrup (2008), nie było w tak pogłębiony sposób „testowane” w dziedzinie tak wyraźnie opartej na ciele i sposobach posługiwania się nim jak kulturowe ekspresje oparte na ruchu.

Podobnie jak Samudra skupiam się na procesie dochodzenia do wiedzy wyłaniającej się z ucieleśnionego doświadczenia. Uczyłem się więc wspinaczki tak, jak robią to wspinacze, dzieliłem z nimi wspólne doświadczenia. Trening i nauka pozwoliły mi wypracować pewien habitus wspinaczkowy, który następnie wykorzystałem podczas serii wyjazdów szkoleniowych i wspinaczkowych w Górach Sokolich (dwa wyjazdy - sierpień i październik 2020) i w Tatrach (dwa wyjazdy, wrzesień 2019 i 2020). $\mathrm{Na}$ te z pozoru różne obszary, uwiedziony być może sentymentem do Polskiego Atlasu Etnograficznego, spoglądam jak na swoiste regiony etnograficzne. Są to bowiem regiony granitu, gdzie jego specyfika dyktuje wspinaczkowe warunki i style pokonywania dróg.

W Górach Sokolich, zwanych Sokolikami, uczestniczyłem w zorganizowanych szkoleniach w zakresie wspinaczki skałkowej oraz wspinaczki z użyciem własnej asekuracji. Wybór Sokolików jest poniekąd oczywisty. Tak jak Ness (2011) umiejscawia swoją etnografię w globalnie „kultowym” Yosemite, tak ja wybrałem lokalnie „kultowe” Sokoliki - miejsce, w którym należy bywać, gdzie zaczynali Wanda Rutkiewicz, Wojciech Kurtyka i Krzysztof Wielicki (Kajca 2019). Z podobnego powodu wspinałem się w „kultowych” Tatrach na Łomnicę i Gerlacha - dwukrotnie z tym samym partnerem, Kacprem, ratownikiem TOPR. Te dwa przejścia traktuję jako rozwinięcie idei „etnograficznego autostopu" (ethnographic hitchhiking) (Malla, Kholina, Jäntti 2017), u podstaw której leży założenie, iż poprzez poruszanie się, ludzie wytwarzają szczególne porządki wiedzy oraz relacje między sobą i ze środowiskiem (de Certeau 1984; Ingold 2011). W ten sposób doświadczają i uczą się nawigowania w konkretnych przestrzeniach oraz ustanawiają relacje między własnymi ciałami i krajobrazem. Poruszanie się jest więc eksploracją i poznawczym aktem splatającym ciało, czas i przestrzeń (Edensor 2010). Wychodzę z założenia, że tak badający etnograf aktywnie zanurza się w określonej sytuacji społecznej (wspinaczce), a także, poprzez ruch, praktyki i dzielenie 
przestrzeni, uzyskuje dostęp do intersubiektywnej warstwy doświadczenia drugiego człowieka - partnera wspinaczkowego.

\section{Kinestetyczna estetyka}

Pozornie topo reprezentuje Ingoldowski model biernej „natury”, a więc oddaje obiektywny i materialny świat przyrodniczy. Jednakże, gdy wrócić do rozważań Lorimer i Lund (2003), zobrazowanej skały nie można rozpatrywać w tak zobiektywizowanych kategoriach. Topo jest bowiem konkretyzacją wiedzy gromadzonej przez kolejne generacje wspinaczy, którą można uznać za wspinaczkowy konsensus, a więc wytworzonej poprzez interakcję między wspinaczami i pozaludzkim podmiotem, jakim jest skała. Droga wiodąca przez skałę jest tym konsensusem, a jej przebieg to wypadkowa kumulujących się interakcji oraz doświadczeń przekazywanych i praktykowanych przez kolejne generacje. Oto jak Julia, znakomita wspinaczka i instruktorka, opowiadała o wytyczaniu dróg

Drogi powstają w zamyśle ich autorów. W popularnych regionach jest mało miejsca na nowe drogi, ale zdarzają się tacy, którzy dostrzegą potencjał i oczyszczą kawałek skały. O, tutaj mogłaby być poprowadzona fajna droga. Zaczynają od przygotowania skały, od oczyszczenia jej z roślinności i kruszyzny. Następnie budują stanowisko, żeby można było testowo taką drogę przejść, czy ona faktycznie jest warta tego żeby inwestować w nią. Teraz jest tak, że jest oddzielna grupa osób, którzy nazywają się ekiperami i są prowadzone kursy na ekiperów, ale kiedyś każdy wspinacz mógł sobie obić drogę. Ci wspinacze starsi datą są jakby od razu z góry traktowani jako ekiperzy. No to zaopatrzają się w sprzęt, który im jest potrzebny do obicia, jakieś stanowisko, punkty asekuracyjne, jak ich stać, w to w ringi, a jak mają mniejszy budżet, to w spity no i obijają. I prowadzą ją, wtedy jest otwarta dla ludzi i zgłasza się ją, w zależności od tego, jaki to jest rejon, to kustosza rejonu i on wtedy powie autorowi przewodnika, żeby ją umieścił w następnym wydaniu (w. 10)

Drogę należy zatem rozumieć jako generacyjną trajektorię ruchu wyrastającą z kulturowych uwarunkowań i społecznych praktyk cielesnych. Sądzę więc, że topo należy rozumieć jako przedstawienie Ingoldowskiego „środowiska” - obszaru aktywności i interakcji zachodzących między ożywionymi i nieożywionymi podmiotami, między przestrzenią a jej użytkownikami.

Na poziome etnograficznym problem ten uwidacznia się, gdy mowa o estetyce dróg wspinaczkowych. Wielokrotnie słyszałem o drogach, które są „ładne” i „brzydkie”, o „ładnym” i „brzydkim” wspinaniu, a nawet o skałach i górach, które wyróżniają się swoją estetyką. O estetyce danej drogi można było wnioskować już na poziomie analizy jej mapy topograficznej, choć to zawsze doświadczenie drogi było źródłem 
doznań estetycznych. Podczas rozmów z trenerami i partnerami wspinaczkowymi wracałem więc do pytania: co to znaczy, że droga jest ładna?

Podczas drugiego wyjazdu w Sokoliki instruktor Marek spieszył na spotkanie Polskiego Związku Alpinizmu dotyczące egzaminu dla kandydatów na kurs instruktorski wspinaczki skałkowej3. Tego dnia trenowaliśmy w Rudawach Janowickich pod tzw. Piecem. Szybkim krokiem wracaliśmy na parking - Marek poprosił mnie, bym go podwiózł. W drodze rozmawialiśmy o wspinaczce i lokalnych skałkach. Marek zaczął opowiadać o tzw. Fajce, skale, która jego zdaniem oferowała „ładne wspinanie i ładne drogi”. Dlaczego te drogi są ładne? - zapytałem. Marek odpowiedział:

- To jest ładna skała, ładna ściana, drogi z prostą linią, drogi logiczne. Nie kluczysz tam raz w prawą, a raz w lewą.

- Ale co oznacza, że droga jest ładna i logiczna?

- Eeee, no wiesz, ładna jest, fajne wspinanie. Hmm...(Marek wykonał kilka ruchów rękoma] (rozmowa spisana w notatkach).

Marek, jak mi się wówczas zdawało, nie umiał odpowiedzieć na tak zadane pytanie. Jednakże, gdy wróciłem do tego problemu wieczorem przy ognisku, zrozumiałem, że odpowiedź Marka była znacząca:

- Co to jest ładna droga? Pierwszy odezwał się Kuba.

- No po prostej drodze idzie, wiesz, tak jest ukształtowana przez naturę. Jak kluczysz, to jakbyśs oszukiwał naturę, jakbyś ją obchodził. Dlatego tak cenione są diretissimy. Potem wtrącit się Adaś.

- Wiesz co, mi się wydaje, że ładna droga to jest ta, którą doświadczasz jako ładną. To subiektywna sprawa.

Na koniec Olaf - drugi instruktor - dodał:

- Droga bez parchów, bez trawek, krzaków, wiesz, taka czysta.

- Ale w linii prostej?

- No wiesz...może i tak, ale...(rozmowa spisana w notatkach).

Wróćmy do Marka. Wbrew moim wcześniejszym odczuciom, udzielił mi on wyczerpującej odpowiedzi. Nie uczynił tego jednak w sposób językowy. Estetyki drogi nie da się bowiem wyrazić w kategoriach oferowanych przez aparat słowny. Estetyka

3 Przebieg egzaminu mogłem obserwować. W istocie jest to trzymające w napięciu widowisko dzielące się na kilka aktów i wymagające od zdających niezwykłych umiejętności, pewności i obycia w skale. Nierzadko też muszą oni wykazywać się nadzwyczajną odwagą i wielkim sercem, szczególnie podczas pokonywania zadanej drogi mającej sprawdzić ich stopień zaawansowania technicznego i możliwości psychofizycznych. Nie trudno zgadnąć, że taka droga nigdy nie należy do łatwych, a sam egzamin przypomina obrzęd przejścia. 
wspinaczkowa, a szczególnie jej doświadczenie, wywodzi się z innego porządku niż opis i mowa. Jej korzeni należy szukać w języku ciała, w ciele doświadczającym, w ciele w ruchu postawionym w specyficznej relacji do danej przestrzeni. To ruch i multisensoryczne poznanie wytwarzają wspinaczkowe doznania estetyczne. Na taką interpretację wskazują również niemalże mimowolne ruchy, które Marek wykonał, gdy odpowiadał na zadane pytanie. To ciało odpowiadało, to ono chciało pokazać, jakie ruchy są ładne. Widzę tu wyraźnie podobieństwa do materiału, a także jego ucieleśnionych źródeł, który w błyskotliwy sposób zaprezentowała Samudra (2008) interpretując praktykowanie silatu. Estetyka wspinaczki, tak jak estetyka ruchu w silacie, wywodzą się z porządków kinestetycznych - to domeny rozpoznawalne i wyrażane jedynie poprzez ruch oraz cielesne doświadczenie.

Linia prosta, a więc forma bez zbędnej ornamentyki, esencja i sedno doznania, może być ceniona z przyczyn jawnie kulturowych - prosta to jasna, najszybsza, a zarazem na swój sposób najdoskonalsza. Jednakże głos Adasia, a także wyczuwalna niepewność Olafa, otwierają pewną interpretacyjną furtkę - ładne drogi nie muszą być proste, a diretissima nie jest uniwersalną manifestacją wspinaczkowego piękna. Choć współczesny krajobraz wydaje się pozornie zdominowany przez linie proste, to jego lokalne wymiary są poplątane, o czym przecież przekonywał Ingold odkrywając głębię relacji między ludzkim umysłem a wytwarzaniem i praktykowaniem krajobrazu. Wnioski płynące z prac - myślę to o Lines: a brief history (2007) i The life of lines (2015) - są wymowne: życie, a także powiązane z nim działania i operacje w czasie i przestrzeni, dalekie są od przyjmowania trajektorii wyznaczanej przez linię prostą. Poruszanie się w krajobrazie, jak zauważa Ingold, jedynie pozornie odbywa się wzdłuż wytyczonych linii, linia prosta nie jest też uniwersalną formą orientacji ani w czasie, ani w zamieszkiwanej przestrzeni.

Podczas rozmowy z Łukaszem, trenerem wspinaczki na sztucznej ściance, poruszyłem temat prostych linii i estetyki dróg. Łukasz, po chwili namysłu, powiedział: „Ładne drogi to są te, które chcesz powtarzać, których ruchy chcesz powtarzać" (rozmowa zapisana w notatkach).

Co dokładnie chciałbym powtarzać? Z pomocą przychodzi fragment etnografii wytworzonej w drodze na zachodniej ścianie Gerlacha. Gerlach nie jest uważany za estetyczną górę oferującą ładne wspinanie. Co tam zatem znalazłem? Przede wszystkim ocean granitu wyrastający pięćset metrów w górę. Kolosalna była góra i droga - „Samuhelov Komín" (UIAA V-4), a także nasze zdziwienie. Słowackie przewodniki taternickie głosiły, iż na drogę składa się 10 wyciągów ${ }^{5}$ pokonywanych w czasie 3,5-5 godzin. Szybko jednak pojęliśmy, że topo nie tylko nie oddaje realnej sytuacji. Drogę, składającą

4 Skala wyceny trudności dróg Międzynarodowej Federacji Związków Alpinistycznych.

5 Jednostka łącząca punkt startowy ze stanowiskiem/punktem asekuracyjnym, do którego zmierza wspinacz. 


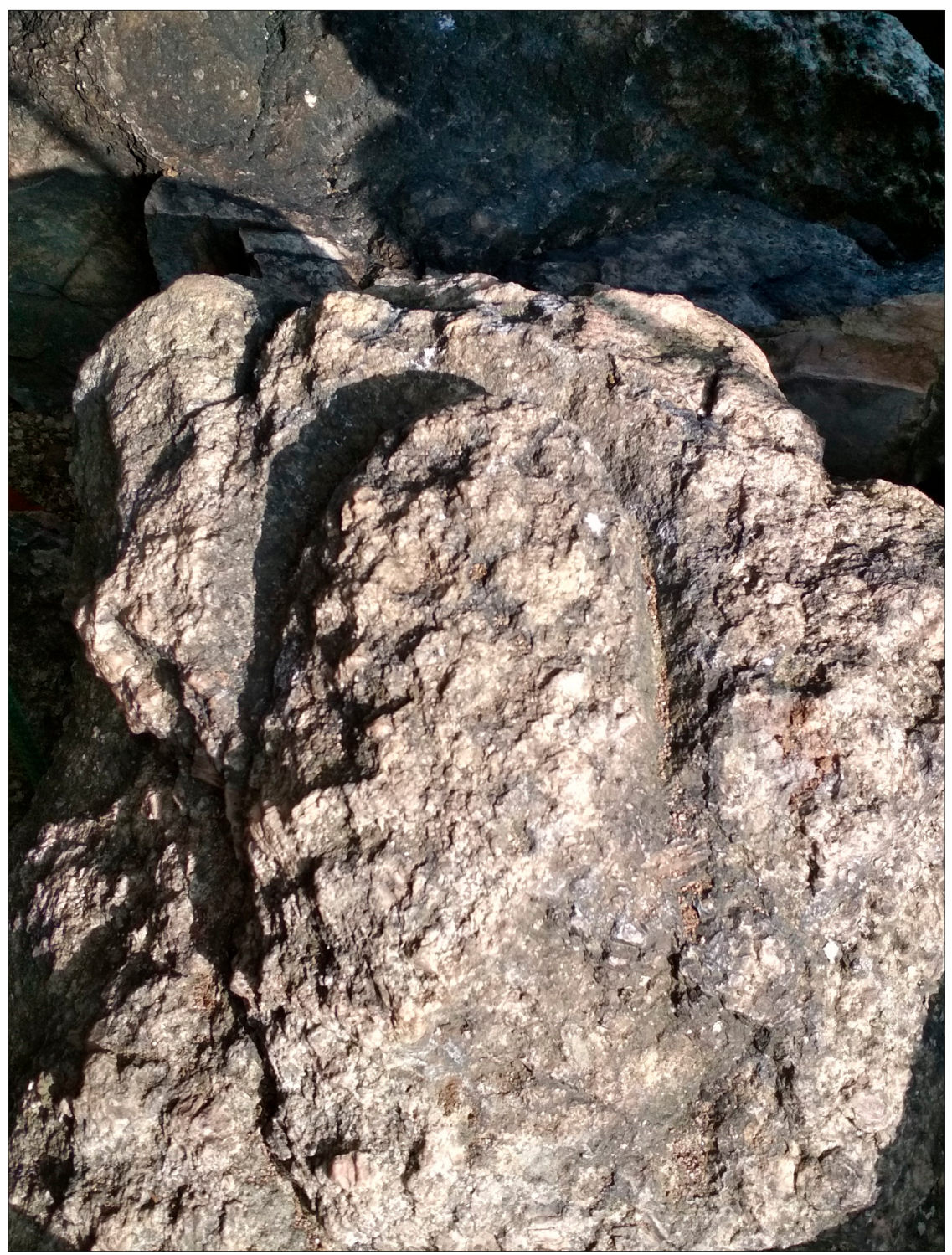

Fot. 2.

Skalne stanowisko zjazdowe - niemy świadek historii; Sokoliki, 2020 r.

się z aż 17 wyciągów, pokonaliśmy w 6 godzin. Było więc dłużej i trudniej - uznaliśmy, że wycena trudności na $\vee$ w skali UIAA jest nieco zaniżona. Odnieśliśmy wrażenie, że słowackie topo przygotowali autorzy znający drogę z zapośredniczonych relacji. Opisana i wyrysowana na zdjęciu linia, tylko na chwilę pozwalała znaleźć się w jakiejś logiczności. Opis drogi korespondujący z naszym doświadczeniem znaleźliśmy w legendarnym przewodniku autorstwa Witolda Paryskiego. Paryski pisze, że droga 
meandruje, że to teren z trudną nawigacją, biegnący przez różne formacje - kominy, płyty, zacięcia i filary. Ciągle więc zmienialiśmy technikę wspinania, nieustannie operowaliśmy ciałem i umysłem, stale zakładaliśmy i zbieraliśmy asekurację i przeprowadzaliśmy operacje sprzętowe, które zapętlały nasze doświadczenie drogi i podważały logikę istnienia prostych linii w tak nieprostym krajobrazie.

Zapętlające okazały się też cechy skały - jej faktura i temperatura - rano śliska i lodowata, a potem już ciepła i pewniejsza. Raz byliśmy w serii kominów, a raz na płytach, które nagle zmieniały się wąską ryskę idealną do klinowania pięści (technika pokonywania niektórych rys). Nigdzie ani śladu po znanej ze wspinaczki skałkowej magnezji, czasem tylko pordzewiałe haki - niemalże archeologiczne artefakty wspinaczkowe - przypominały o poprzednikach. Gdyby nie haki, można by odnieść wrażenie, że nie ma tu śladów człowieka. A jednak droga jest opisana w przewodnikach i poddana pewnej obiektywizacji - ten skalny chaos został przez kogoś uporządkowany. Cały więc czas podążaliśmy po zawiłej nitce utkanej z ludzkiej myśli i percepcji, choć pozornie żadnej myśli i ludzkiego spojrzenia tam nie było.

Nie ma tu więc prostej linii, choć jak mówił Kacper, „było to piękne tatrzańskie wspinanie". Był za to, jak podkreśla Goodrich (2004), nacisk na praktykę i doświadczenie, na odnajdywanie, wytwarzanie i odtwarzanie drogi w ruchu, w relacji do skały oraz do interaktywnego środowiska. Jedną ze strategii opanowania środowiska skalnego, a zarazem formą jego estetycznego doświadczenia, jest stan świadomości mięśniowej. Świadomość ta służy nie tylko do operowania w krajobrazie - to też kulturowy filtr, w którym przydawane są mu walory estetyczne. Zatem ładna droga to ta, którą wspinacz kinestetycznie rozumie i docenia, którą chce zamieszkać, do której pragnie przyłożyć swój wielozmysłowy aparat poznawczy. To droga, z której czerpie się przyjemność ruchu, ale także, jak zauważył Marek, oferująca lokalnie ujętą logikę. To droga, w której wspinacz doświadcza logiki ruchu pozostawionej mu przez wcześniejsze generacje, gdzie może nawiązać do dziedzictwa ukrytego w skale, do wielogłosowej opowieści jaką jest skała z wiodącą przez nią drogą i jej wariantami.

Wracając do myśli K. Hastrup (2018) należy stwierdzić, że wiedza wspinacza to efekt procesualnego zrozumienia i zaangażowania w świat, które odkrywają walory estetyczne nieożywionego krajobrazu. Jednakże, w istocie estetyka wspinania to ukłon w stronę wydawałoby się niewidzialnych minionych generacji wspinaczy, oddanie czci pionierom drogi, estetyzacja ludzkiej praktyki, emocji i doświadczenia pokoleń wspinaczy. Estetyka jest więc emocją, a ładne wspinanie, to wspinanie emocjonalne, wiedza kinestetyczna, do której chce się wracać. To też opowieść o subiektywnych zmaganiach, jednakże postawionych w odniesieniu do dziedzictwa tych, którzy byli tu przed nami, choćby pozostały po nich tylko zardzewiałe haki, wytarte chwyty czy odbicia magnezji. To te subtelne znaki obecności rysują w krajobrazie nić wiodącą na szczyt, to one przypominają, że wciąż jesteśmy w kulturowej przestrzeni, choć pokusą jest stwierdzenie, iż wspinaczka, szczególnie ta górska, jest wyjściem 
na chwilę poza ramę ludzkiego świata. Jednakże, jak przekonuje Marek Pacukiewicz (2012), w istocie wspinacze poruszają się po grani ustanawiającej granicę między ich jeszcze ludzkim światem a przestrzenią już pozaludzką. Te zmagania są zatem same w sobie konstytuujące - określają granice fizycznych i psychicznych możliwości, pokazują, gdzie i jak przebiega granica między światem człowieka a światem bezładnej natury. Ten ostatni zdaje zaczynać się tam, gdzie kończy się człowiek i jego aktualne możliwości. Nie można więc rozpatrywać wspinaczki w sposób poniekąd bez-historyczny, jak czyni to Goodrich (2004), uznając historyczne przedstawienia dróg za obrazy odcinające ich nosicieli od doświadczenia in situ. Te obrazy to nie tylko mapy przebiegu drogi, ale również reprezentacje zmagań człowieka o to, aby grań, o której wspomina Pacukiewicz, przenosić dalej, wyżej i ku większym stromiznom, co w wymowny sposób obrazuje przecież gwałtowny rozwój skali trudności pokonywanych dróg6. Dzięki tym historiom, jak zauważa Rossiter (2007), kolejne urwiska nabywają kulturowego znaczenia, a pokonujący je ludzie stają się podmiotami-wspinaczami. Podążając za myślą Hastrup (1994) należy powiedzieć, że krajobraz to przestrzeń praktykowana oraz wyrastająca z historii i społecznej pamięci, z praktyk oraz doświadczeń, których refleksy można znaleźć w skalnej masie. Wspinaczka jest więc formą odtwarzania historii - czasem wydawałoby się milczących i zardzewiałych, jak haki, oraz wygładzonych, jak chwyty w skale - jednakże stale na nowo odkrywanych i doświadczanych przez kolejne generacje wspinaczy, które same przecież piszą własną historię.

\section{Doświadczanie drogi: habitus, nie-aktywność, ruch}

Wspinaczka to proces wypracowywania świadomości mięśniowych, które Łukasz Smyrski interpretuje jako emiczne sposoby poruszania się w krajobrazie (2018: 133-136). Jak zauważa J. Dutkiewicz (2015), wspinanie jest również budowaniem pewnego habitusu, a więc zaplecza społecznego. U Peirre`a Bourdieu habitus tworzy zespół podzielanych i nabytych kompetencji, strategii i umiejętności stanowiących bazę do poruszania się danym świecie. Habitus to domena aktywnie zaangażowanego ciała, praktyczna wirtuozeria w operowaniu ciałem (Bourdieu 1977: 87). Habitus jest elastyczny, przez co obrana przez jednostkę strategia działania może ulec zmianie wraz ze zmieniającymi się warunkami działania. Rzeczywiście, podczas prowadzonych rozmów i w obserwowanych sytuacjach nie raz miałem wrażenie, że wspinaczkowy habitus jest bardzo elastyczny. Oto fragment rozmowy Julią:

6 Popularna w Polsce tzw. Skala Kurtyki dobrze oddaje istotę problemu. Wojciech Kurtyka zaproponował w latach 70. XX w. nowy system wyceny trudności dróg wspinaczkowych w skałach głównie wapiennych, ponieważ w lokalnym środowisku wspinaczkowym dojrzewało przekonanie, iż dostępny wówczas system wyceny - kończący się na stopniu VI (ekstremalnie trudno) - nie oddawał faktycznych trudności pokonywanych przez kolejne i coraz lepsze generacje wspinaczy. 
Pamiętam ten moment, jak odkryłam, jak coś zrobić łatwiej i potem mam to zaplanowane. Ale jest tak, że na przykład, jak robiłam jakąś drogę kilka lat temu i miałam inny styl i przeszłam ją w jakiś tam sposób, dzisiaj przechodzę ją ponownie i przechodzę ją inaczej. Myślę sobie -zapamiętałam ją jak była trudniejsza, ona była naprawdę trzymająca trudność! Po czym idzie mój kolega i znajduje te chwyty, które ja znalazłam pięć lat temu, których teraz nie potrzebowałam, więc nie szukałam ich, tylko szłam tak, jak mi przyszło do głowy (w. 10).

Tak rozumiany habitus, korespondujący z Hastrupowskim enskilment, wprowadza więc pewną elastyczność, ale także rutynowość działania. Wytwarzanie map topograficznych, podobnie jak nabywanie umiejętności i technik wspinania, w istocie mają taki charakter, o czym słusznie przekonuje Dutkiewicz (2015). Habitualne są także te działania, które nie wiążą się z aktem wspinaczki, a czasem wręcz ją uniemożliwiają. Jak to możliwe?

Czekanie jest integralną częścią wspinaczki i wspinaczkowej etykiety. Choć przygodne, jest także swoistą umiejętnością. Czekać można na dobrą pogodę, ale też na tę złą, która zmusza do odwrotu. Podczas sierpniowego wyjazdu w Sokoliki prognozy (zwane potocznie wśród wspinaczy „meteo”) zapowiadały deszcze. Mimo to wyszliśmy w teren. Otoczony drzewami i skoncentrowany na prawidłowym zakładaniu asekuracji na „Grzybowych Ryskach”, przeoczyłem znaki nadchodzącej ulewy, która zaskoczyła mnie przy przewiązywaniu się przez stanowisko, a więc w dość niebezpiecznym momencie. Instruktor wiedział, że nie lubię deszczu w górach. Zdaje się, że drażniło go moje częste sprawdzanie prognoz, dlatego, gdy już zeszliśmy na dół, wygłosił, patrząc się na mnie: „Musicie zrozumieć, że jeśli chcecie się wspinać, to czasem będziecie musieli też zmoknąć. To normalna część wspinania" (rozmowa spisana w notatkach).

Podczas drugiego wyjazdu w Sokoliki również przyszedł deszcz. O wspinaniu nie było mowy - ćwiczyliśmy, zmarznięci i mokrzy, operacje sprzętowe na pniach drzew, z których lała się woda. Zmieniliśmy pasmo - pojechaliśmy pod rudawski „Piec”, z nadzieją, że skalny okap ochronił skałę, lecz i tu było mokro. Uświadomiłem sobie, że brak wspinania - paradoksalnie - może być też częścią doświadczenia wspinania, a braku wspinaczki należy się uczyć. Czekanie jest więc konstytutywną częścią procesu wspinaczkowego poznania, podczas czekania przyswaja się różne formy wiedzy, studiuje topo lub trenuje inne elementy. Czekanie to czas frustracji, często rozładowywanej poprzez dostępne struktury narracyjne. Wspinacze, gdy czekają, snują opowieści o czekaniu - jak choćby przy wieczornym ognisku, przy którym mieliśmy się ogrzać i wysuszyć. Gdy spoglądam do notatek z tego wieczora, widzę streszczone historie o czekaniu z dominującym motywem bez-ruchu. To opowieści o tym, kto, gdzie i jak długo czekał w schronisku, kogo złapała w górach burza, a kogo powstrzymał deszcz 
czy lawinowa „trójka”? Język zatem przychodzi tu z pomocą, narracja rozładowuje napięcie, daje nadzieję na to, że czekanie nie jest aberracją i jednostkowym doświadczeniem pecha.

Czekać można także na tzw. warun. Pod tym żargonowym terminem, kryje się multisensoryczny świat znaczeń, a także praktyka rozpoznawania optymalnych warunków wspinaczkowych. Dobry warun to zatem właściwe temperatura i wilgotność powietrza, optymalne tarcie skały oraz nasłonecznienie. Dobry wspinacz umiejętnie rozpoznaje dobry warun. Wspinacze zwracają uwagę na detale pozornie niewidoczne - a robią to poprzez uważną i umiejętną obserwację, zestawianie prognoz pogody z własnym i lokalnym doświadczeniem panujących warunków i poprzez - jakby powiedziała Hastrup - wnioskowanie - forecasting. Są więc wspinacze podobni do arktycznych myśliwych, którzy wiedzą, kiedy udać się na polowanie. Wpinacze wiedzą, kiedy są warunki na „upolowanie drogi”.

Ocena warunu to stały element dnia wspinacza. Rano można spotkać ludzi, którzy w umiejętny sposób dotykają płaszczyzn i skalnych krawędzi. Szukają zawilgoconych miejsc, niepewnych i śliskich chwytów i błota ukrytego w skalnych pęknięciach. Sprawdzają, jak „skała trzyma”. Ten swoisty „rytuał palpacyjny” (mój termin) wydał mi się szczególnie widowiskowy pod wymagającym „Nosem Żubra”. Dwóch wspinaczy przyszło pod "Nos”, gdy my działaliśmy na drogach obok. Jeden z nich, podwieszony na linie, starannie dotykał skały w kluczowych punktach, przyglądał się jej w milczeniu, przesuwał dłoń wedle wskazówek tego, który stał na dole, by wreszcie wydać wyrok: „Jest warun, stary, jest warun!” (sytuacja opisana w notatkach).

Umiejętnie rozpoznanie warunków jest więc sztuką. Jednakże sztuką jest także nie-wspinanie. Zaniechanie próby to nie tylko praktyka eliminująca ryzyko, ale także walka o rangę trofeum. Przejścia zakończone sukcesem są bowiem wykonywane w tzw. stylu, co podkreślali wspinacze: „Kiedy przeszłam drogę? Kiedy przeszłam ją w stylu. Nie liczę sobie wędek i AF-ów, tyko OS, Flashem albo RP" (w. 8).

Najwyżej ceniony w środowisku jest „OS” (on-sight), a więc pokonanie drogi bez wcześniejszych prób i obserwacji innych wspinaczy. Gdy wspinacz powtórzy czyjąś „betę”, uzyskuje tzw. Flash. Natomiast mianem „RP” (Red Point), określa się wejście bez obciążania liny dopiero w którejś próbie (Donahue, Luebben 2017). Zaniechanie wspinaczki i zachowanie czystego konta należy więc także do wspinaczkowego habitusu. Sam zresztą mogłem się o tym przekonać, gdy po deszczowym dniu i nocy wstawiłem się w „Krwawą Rączkę”, drogę, z którą mam porachunki. Próba okazała się frustrującą porażką. Gdy okazało się, że w kluczowym momencie wszystkie ryski i chwyty były mokre, wspinaczka w zasadzie straciła sens. Topo stało się jedynie bezsensownie namalowaną linią, droga nie-drogą - skałą, której nie sposób było się chwycić, która pociemniała od wilgoci i jakby ukryła się przed oczyma nań patrzących,

7 Trzeci stopień zagrożenia lawinowego uważany za poważną przeszkodę w działalności górskiej. 
przed rękoma i stopami wspinaczy. Próżno było szukać nici ludzkiej logiki, wszystko zmył deszcz. Skała została odarta z przydanego jej znaczenia, stała się jedynie biernym obiektem, który będzie można ożywić dopiero, gdy wróci warun. Choć bez sukcesu, to z otwartym nowym polem do refleksji, zjechałem na dół - ten surowy moment uświadomił mi, że rytuał palpacyjny nie jest tylko pustą formą, a złożonym rozpoznaniem i wnioskowaniem. To chwila, w której nabyte doświadczenie i rozumienie mówią wspinaczom, czy dziś jest szansa, by wrócić z trofeum, czy może lepiej zająć się „zbieractwem” łatwiejszych dróg.

Są także aktywne sposoby czekania. Wielokrotnie słyszałem, że rozmówcy, szczególnie ci bardziej zaawansowani, czekali na konkretną drogę, wymagającą sprecyzowanego przygotowania fizycznego i mentalnego. Wiedzieli, że na przykład "Neuroleptyk” (jezdna z dróg wspinaczkowych, którą musieli pokonać w sposób tradycyjny kandydaci na kurs instruktorski) kończy się trudnym wyjściem na płytę, uczyli się zakładać asekurację w określonych typach punktów, ustawiając przy tym ciało w specyficzny sposób - tak jak będą musieli to zrobić podczas przejścia drogi.

Czekać można w kolejce przy skale, szczególnie w pogodne dni weekendu. Czeka się na początek drogi, na pierwszy kontakt ze skałą, który, jak opowiadała mi Julia, jest niemal zawsze elektryzujący i badający jednocześnie. To kontakt, który otwiera przepływ informacji, ustanawia początek relacji między wspinaczem a skałą. Podobnie czeka się na chwilę, gdy już będzie wiadomo, która z nici w skale jest nasza, jak i dokąd wiedzie. Takie czekanie nabiera dramatycznego wymiaru w górach, o czym opowiadał mi Kacper. Choć samo podejście do ściany bywa nużące, to wypełnione jest myślami i oczekiwaniem na widok - jednocześnie olśniewający i onieśmielający - gdy przed wspinaczem ściana odsłania oblicze. Gdy już w ścianie się jest i pokonuje się ją dzięki wyuczonym technikom i strategiom działania, czeka się na tzw. crux, czyli najtrudniejsze miejsce stanowiące o wycenie drogi (Donahue, Luebben 2017).

W skałkach sprawa jest łatwiejsza - takie miejsca najczęściej po prostu widać. W górach jednak cruxy są ukryte i trzeba do nich dotrzeć, by w ogóle móc ocenić swoje szanse. Choć wspinacze pamiętają informacje z topo, które przeważnie mają je ze sobą, to oczekiwanie na kulminacyjne punkty drogi są nieodłączną częścią doświadczenia ruchu w skale - sam przecież czekałem na Gerlachu na kluczową „przewieszkę" (miejsce z przewieszoną skałą), opisaną (zresztą mylnie) jako najtrudniejszy punkt drogi. Gdy już wspinacz takie miejsce dostrzega, następuje akt mobilizacji, chwila, być ocenić, gdzie można założyć ostanie pewne punkty asekuracji. To także, jak pokazał mi Kacper, czas uważnego lustrowania własnego ciała, można powiedzieć chwila samooceny, która musi zaowocować kilkoma ważkimi decyzjami - podejmę próbę, czy nie?; kto poprowadzi ten wyciąg?; czy jestem pewny swoich umiejętności? Znów więc mowa o pewnym surowym momencie, przewidywaniu, symulacji ruchów, szukaniu odpowiednich ich sekwencji, ocenie panujących warunków i stanie ciała. To więc chwila stricte epistemologiczna, czas produkowania wiedzy poprzez uważną 
wielozmysłową obserwację, introspekcję, rozmowę/współpracę z partnerem, a wreszcie przez praktykę cielesną, ruchy, które są jedynie fizycznym zwieńczeniem złożonego, wielozmysłowego i mentalnego procesu, jakim jest poruszanie się w skalnym chaosie po nici ludzkiej logiki i doświadczenia.

Topo zawiera także informacje, gdzie ruch może być wstrzymany - w celu odpoczynku lub zamiany prowadzącego. Instruktorzy jak mantrę powtarzali nam, że dobry wspinacz wie, gdzie może odpocząć, potrafi rozpoznać w skale formacje sprzyjające regeneracji. Można tu mówić o całym zespole technik i strategii relaksowania mięśni, których adepci wspinaczki uczą się już od początku. Pamiętam, jak z początku niemożliwe wydawało mi się, a także moim partnerom wspinaczkowym, osiągnięcie pozycji tzw. no-handa, czyli momentu, w którym całkowicie należy puścić chwyty i zaufać jedynie nogom i stopniom. Takie działania, przynajmniej z początku, wydają się bowiem sprzeczne z logiką, są niejako przeciwne wobec instynktu samozachowawczego. Wspinanie się przeczy więc ucieleśnionym logikom i mentalnym stanom, które są składową instynktu przetrwania - wspinacz musi umiejętnie ten instynkt w sobie zwalczyć, a atawistyczne i behawioralne działania zastąpić szeregiem wyuczonych praktyk i strategii ze wspinaczkowego habitusu. To zwalczanie instynktu i wprowadzanie nowych technik do ciała jest formą enskilment. Obrazuje to fragment rozmowy z Julią:

Jeśli nie jest mi dane prowadzić drogę OS-em, tylko robi to ktoś inny, to zwykle jak zjeżdża - ja wspinam się z Piotrem, moim partnerem wspinaczkowym - i na przykład mówi: no tam na wysokości czwartej wpiny to jest stopień, ale jest kiepski, to musisz uwierzyć, że na nim stoisz, że tak odważnie na nim stoisz, bo naprawdę trzyma. A tamten chwyt, to się wydaje, że się go łapie z góry, a tak naprawdę to nie, bo będzie lepiej, jak go złapiesz z boku (w. 10).

Praktyka wspinania to zatem praktyka poskramiania emocji i instynktów, to zastępowanie cielesnych i mentalnych automatyzmów treścią, która dekonstruuje wydawałoby pierwotną logikę ciała, a zastępuje ją wyuczoną strategią. Chwyty, które wydaje się, że należy trzymać tak, jak trzyma się zazwyczaj przedmioty, odkrywają przed wspinaczem inne kąty i płaszczyzny, a stopnie, które w ogóle stopniami się nie wydają, stają się wygodnymi punktami, w których istnienie trzeba właśnie uwierzyć. Mowa więc o złożonej formie nauki oraz praktyki haptycznej i kinestetycznej wyrastającej z wielozmysłowego zaangażowania ciała będącego w ruchu. Ta nauka i praktyka ożywia wyrysowaną drogę, nadaje sens liniom i logikom nałożonym przez generacje wspinaczy na skałę. To poprzez ruch, który jest osadzony w społecznych i kulturowych tradycjach oraz konwencjach, fragmenty skały zamieniają się w opisane na topo formacje, wspinacz "odkrywa” chwyty i stopnie, rozpoznaje logikę poruszania się w skale i wytwarza swoją „betę”, a więc wiedzę i sekwencję właściwych ruchów i strategii, które pozwalają mu odnieść sukces. 


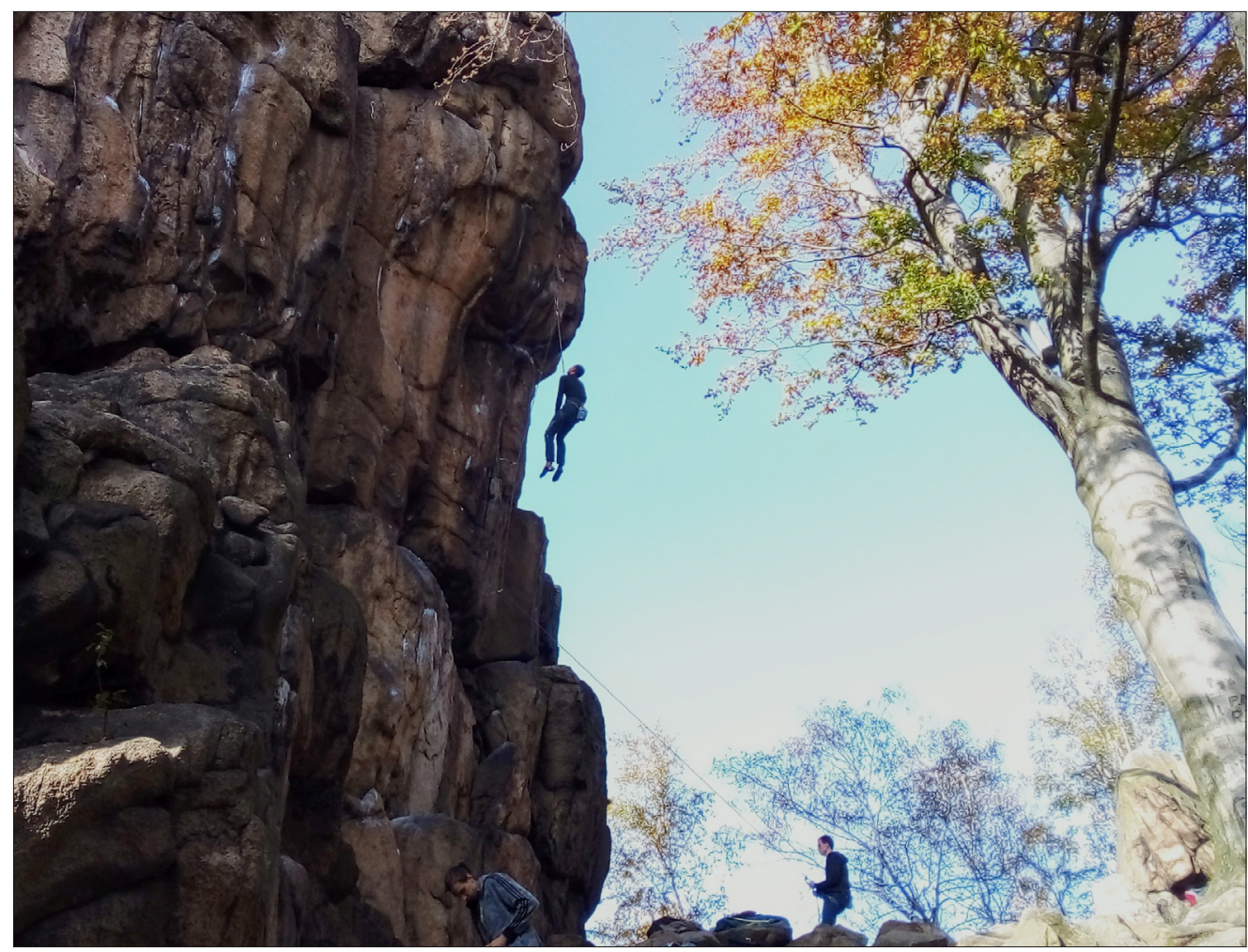

Fot. 3.

W poszukiwaniu „bety”; Sokoliki, 2020 r.

Wspinaczka, jak zauważają Ness (2011) i Rossiter (2007), to akt wzajemnego definiowania się - skały i wspinacza jednocześnie. Skała bowiem staje się obiektem społecznie i kulturowo użytecznym wtedy, gdy wspinacz, a więc nosiciel tożsamości, która bez skały istnieć nie może, zechce ją, mówiąc językiem Ingolda (2000), zamieszkać i praktykować. Obiekty bowiem, jak mówi ten antropolog, nie są dane z góry, tak jak z góry nie są dane skały i wiodące przez nie drogi. Są one przyczynkami do działania, które, wracając do słów Julii, powodują, że w zamyśle wspinaczy powstają drogi wiodące jedynie pozornie niewidocznymi liniami.

\section{Wnioski}

Jednym z problemów wspinaczki jest relacji między graficzną reprezentacją drogi zawartą na mapie a wielozmysłowym doświadczeniem świata. Ciało wspinacza jest bowiem zaangażowane na wiele nieoczywistych sposobów, to ciało wytwarzające mnogość materialnych i niematerialnych wymiarów rzeczywistości nieuchwytnej dla reprezentacyjnej mapy topograficznej. W tym sensie Goodrich (2014) miał 
rację - wspinaczka każdorazowo pociąga za sobą konieczność ponownego zdefiniowania wydawałby się pasywnego świata skał, którego faktycznej dynamiki topograficzne czy mentalne reprezentacje uchwycić zwyczajnie nie mogą. Jednakże Nan Shepherd pisze:

Ich fizjonomia opisana jest w książkach geograficznych - tyle mil kwadratowych, tyle jezior, tyle szczytów sięgających ponad 4 tyś. stóp. Jednakże, to jedynie bezbarwne symulakrum ich prawdziwej natury, która, jak każda rzeczywistość znacząca dla człowieka, jest w istocie domeną jego umysłu (Shepherd 2011: 1).

Takie też są drogi wspinaczkowe - to drogi ludzkiej myśli w nieludzkim, choć uczłowieczonym krajobrazie, drogi, które są wypadkową interakcji zachodzących między odrzucanymi przez Goodricha reprezentacjami a szerszym wspinaczkowym uniwersum, na końcu którego wyłania się przecież krajobraz ubrany w znaki, symbole i doświadczenia spływające ze świata. Ten krajobraz, jak chce Rossiter (2007), to efekt mediacji między człowiekiem i jego wspinaczkowym habitusem, dostępną technologią oraz skałą i jej właściwościami. Tak pojmowaną przestrzeń należy interpretować jako Ingoldowskie środowisko, a więc obszar wielopodmiotowej aktywności i interakcji. Kazus wspinaczki przenosi więc odwieczną dyskusję o relacji między naturą i kulturą do innego porządku - podważa sens istnienia tej dychotomii i wpisuje się w refleksyjny oraz dekonstruujący nurt w badaniach krajobrazu, który krystalizował się w światowej antropologii już od lat 80. XX wieku (Smyrski 2018). Nie ma więc natury bez kultury, ani kultury bez natury. Nie ma skały bez wspinacza i wspinacza bez skały. Wszystkie te elementy i tożsamości powstają w relacji do/między zróżnicowanymi podmiotami i przestrzeniami, są konsekwencją praktyk cielesnych i przestrzennych osadzonych w lokalnych kontekstach społecznych i kulturowych genealogiach.

Topo zatem jest graficzną formą zapisu tychże kontekstów i genealogii, jest przedstawieniem sumy ludzkich doświadczeń i praktyk. To reprezentacja wynegocjowanej logiki ruchu i spojrzenia na niematerialne podmioty. Jakże więc cieszą oko wspinacza i etnografa rozgałęziające się linie dróg, tworzące warianty, a więc graficzne emanacje, a także zapisane w skale historie różnorodności ludzkiego doświadczenia i mnogości logik przestrzenno-ruchowych. Te wijące się i czasem przecinające linie tworzą zatem zawiłą sieć historii przestrzennych i kinestetycznych opowieści o praktykach, doświadczeniach i sposobach poznawania w ruchu i poprzez ruch. Choć często w przewodnikach przedstawiane są jako (w miarę) proste linie, w praktycznym już świece trajektorie te meandrują, tak jak przecież meandruje ludzka myśl i doświadczenie. Należy pamiętać, że o tym doświadczeniu decydują nie tylko odarte z multisensorycznej głębi stopnie i chwyty powiązane jakąś sekwencją ruchów. Skała ma bowiem zapach i temperaturę, może być dostępna, jak w Sokolikach, ale może być także ukryta na końcu długiej drogi, tak jak ukryta jest zachodnia ściana Gerlacha. Nie ma więc linii 
prostych - są poskręcane, trójwymiarowe i multisensoryczne doświadczenia ulegające przekształceniom w czasie. Tę samą drogę, choć jej mapa pozostaje niezmienna, w różnych okresach aktywności można pokonywać na różne sposoby, w drogach raz już przebytych ciągle jest potencjał poznawczy - da się je odczytywać na nowo, na nowo wstawiać się do zapętlającej się trajektorii wiedzy i doświadczeń kolejnych generacji praktyków skały.

\section{Bibliografia}

Bourdieu, P. (1977). Outline of a Theory of Practice. Cambridge: Cambridge University Press.

de Certau, M. (1984). The Practice of Everyday Life (przeł. S. Rendall). Berkeley: University of California Press.

Donahue, T., Luebben, C. (2017). Wspinaczka w skale (przeł. T. Kliś). Łódź: Galaktyka.

Dutkiewicz, J. (2015). Pretzel Logic: An Embodied Ethnography of Rock Climbing. Space and Culture, $18(1), 25-38$.

Edensor, T. (2010). Walking in Rhythms: Place, Regulation, Style and the Flow of Experience. Visual Studies 25(1), 69-79.

Goodrich, A. (2004). Scaling Culture: Rock Climbing and the Embodied Nature of Spatial Knowledge. Anthropology Southern Africa, 27(1), 27-34.

Hastrup, K. (1994). Natura jako przestrzeń historyczna (przeł. S. Sikora). Konteksty. Polska Sztuka Ludowa, 48 (3/4), 8-13.

Hastrup, K. (2008). Droga do antropologii. Między doświadczeniem a teorią (przeł. E. Klekot). Kraków: Wydawnictwo Uniwersytetu Jagiellońskiego

Hastrup, K. (2010). Emotional Topographies: The Sense of Place in the North. W: J. Davies, D. Spencer (red.), Emotions in the Field (s. 191-212). Palo Alto: Stanford University Press.

Hastrup, K. (2018). Muscular Consciousness. Knowledge-making in an Arctic Environment. W: T. Rakowski, H. Patzer (red.) Pre-textual Ethnographies: Challenging the Phenomenological Level of Anthropological Knowledge-making (s. 116-137). Canon Pyon: Sean Kingston Publishing.

Hayden, L., Lund, K. (2003). Performing Facts: Finding a Way over Scotland's Mountains. The Sociological Review, 51(2), 130-144.

Ingold, T. (1993). The Temporality of the Landscape. World Archaeology, 25(2), 152-174.

Ingold, T. (2000). The Perception of the Environment. Essays on Livelihood, Dwelling and Skill. London-New York: Routledge.

Ingold, T. (2007). Lines: A Brief History. London-New York: Routledge.

Ingold, T. (2011). Being Alive. Essays on Movement, Knowledge and Description. London: Routledge. Ingold, T. (2015). The Life of Lines. Oxon-New York: Routledge.

Kajca, M. (2019). Góry Sokole. Przewodnik wspinaczkowy. Kraków: Góry Books.

Kolbuszewski, J. (2020). Góry. Przestrzenie i krajobrazy. Studia z historii literatury i kultury.

Kraków: Wydawnictwo Universitas.

Malla T., Kholina A., Jäntti L. (2017). Urban Hitchhiking: Wandering with Others as a Research Method. Suomen Antropologi, 42(3), 41-51. 
Ness, S.A. (2011). Bouldering in Yosemite: Emergent Signs of Place and Landscape. American Anthropologist, 113(1), 71-87.

Pacukiewicz, M. (2012), Grań kultury. Transgresje alpinizmu. Kraków: Wydawnictwo Universitas.

Rossiter, P. (2007). On Humans, Nature and Other Nonhumans. Space and Culture, 10(2), 292--305.

Samudra, J.K. (2008). Memory in Our Body: Thick Participation and the Translation of Kinaesthetic Experience. American Ethnologist, 35(4), 665-681.

Shepherd, N. (2011). The Living Mountain. Falkirk: Canongate Books.

Smyrski, Ł. (2018). Między władzą spojrzenia a praktyką. Antropologia krajobrazu. Warszawa: Wydawnictwo Oficyna.

\section{Spis fotografii}

Fot.1. Widzialna droga. Sokoliki, 2020 r. Fot. H. Wierciński.

Fot.2. Skalne stanowisko zjazdowe - niemy świadek historii. Sokoliki, 2020 r. Fot. Ł. Depta.

Fot.3. W poszukiwaniu „bety”. Sokoliki, 2020 r. Fot. H. Wierciński.

\section{Streszczenie}

„Topo" to mapa drogi wspinaczkowej i skała poddana obiektywizacji. Dostarcza ona pierwszej wiedzy o danej drodze. Mapy nie są jednak tylko przedstawieniami obiektów przyrodniczych, lecz także reprezentacjami złożonych, ucieleśnionych oraz temporalnych praktyk społecznych. Wspinaczka to zatem pewien cielesny stan i epistemologiczna dyspozycja, dzięki którym wspinacz pokonuje kolejne metry skały. Postawione w artykule pytanie brzmi zatem: jak wytwarzana jest ta wiedza i doświadczenie; jak przebiega tranzycja z wiedzy pierwszej, wydawałoby się zobiektywizowanej, ku subiektywnej wiedzy rodzącej się podczas aktu wspinania?

Słowa klucze: wspinaczka, ucieleśnienie, doświadczenie, krajobraz

\section{Summary}

"Topo" is the objective map of climbing routes, providing the initial knowledge of the given route. However, maps are far from being merely objective representations of natural objects; in fact, they represent complex and embodied social practices. Climbing, then, is a certain bodily state, an epistemological disposition, and the knowledge of the right moves. Thus, the question posed in the article is how precisely this knowledge and experience emerge; how the first knowledge of the route is transformed into subjective experiences and embodied knowledge.

Keywords: climbing, embodiment, experience, landscape

Translated by Author 

materiaty z terenu 
